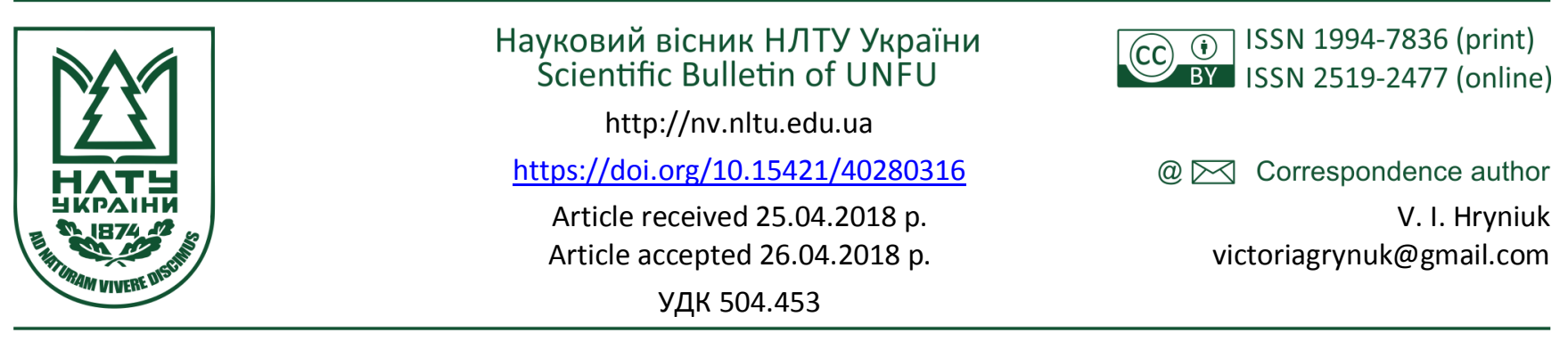

В. І. Гринюк

Івано-Франківський національний технічний університет нафти і газу, м. Івано-Франківськ, Украӥна

\title{
ДОСЛІДЖЕННЯ ПРОЦЕСІВ САМООЧИЩЕННЯ ПРАВИХ ПРИТОК РІЧКИ СВІЧІ БАСЕЙНУ ДНІСТРА
}

Представлено результати досліджень процесу розбавлення стічних вод, які надходять до правих приток річки Свічі басейну Дністра. Описано проблеми забруднення малих річок у межах впливу нафтогазової промисловості. Визначено чинники впливу на природний процес самоочищення річок. Обгрунтовано методику визначення кратності та інтенсивності процесу розбавлення стічних вод у річках Тур'янка, Саджава та Лущава. Проаналізовано статистичні дані екологічного моніторингу Долинського підприємства нафтогазової промисловості за період 2007-2016 pp. На основі щоквартальних даних відбору проб води обчислено середнє значення концентрацій хімічних елементів за рік у місці скиду стічних вод, 500 м вище та 500 м нижче випусків № 1, 2, 3, 4 Долинського підприємства нафтогазового комплексу. Внаслідок виявлено перевищення гранично допустимої концентрації за такими забруднювальними речовинами: хлориди, амоній сольовий, нітрити, азот амонійний та біохімічне споживання кисню (БСК $)$, за якими здійснено подальший розрахунок показника інтенсивності розбавлення стічних вод у річках Тур'янка, Саджава та Лущава. Зображено та проаналізовано динаміку зміни біохімічного споживання кисню на ділянці 500 м вище та 500 м нижче від місця чотирьох випусків стічних вод. Проведені розрахунки підтверджують закономірність: із збільшенням швидкості течії річки підвищується кратність розбавлення, а також свідчать про забруднення правих приток річки Свічі, природний процес самоочищення яких відбувається дуже повільно.

Ключові слова: стічні води; забруднювальні речовини; кратність розбавлення; нафтогазова промисловість; біохімічне споживання кисню.

Вступ. Скидання стічних вод промисловими підприємствами з різним вмістом органічних, бактеріальних та хімічних забруднювачів призводить до зниження якості води у природних водотоках. Своєю чергою, забруднювальні речовини впливають на органолептичні властивості води в річках, надають їй неприємного присмаку, запаху, а також впливають на біохімічні процеси, тобто сповільнюють чи повністю пригнічують природний процес самоочищення.

Хоча промислові підприємства проводять попередню очистку зворотних вод перед їх скидом, проте, як показують дослідження, у природні водотоки потрапляють забруднювальні речовини. Щорічно в басейни річок України скидають близько 9,6 млрд м ${ }^{3}$ недостатньо очищених стічних вод, зокрема 2,9-4,0 млрд м³ забруднених (Adamenko et al., 2007).

У наукових працях багатьох учених (Arkhypova \& Pernerovska, 2015; Korchemlyuk, 2015; Karpets, 2014; Proskurnyn, 2015; Malovanyy et al., 2016; OshurkevychPankivska, 2016; Jakubínský, 2014; Salla, 2016; Swain \& Sahoo, 2017; Zaharia, 2017) та ін. досліджено фізичні, хімічні та біологічні процеси, що відбуваються у водних екосистемах.

Дослідженню гідрохімічних процесів, які відбуваються у малих річках Карпатського регіону під час скидання недостатньо очищених стічних вод, приділяють значно менше уваги. При цьому особливої актуальності набуває питання щодо дослідження процесу самоочищення малих річок, які перебувають у зоні впливу нафтогазової промисловості.

Мета роботи - проаналізувати процес природного самоочищення правих приток річки Свічі Карпатського регіону.

Для досягнення поставленої мети потрібно виконати такі завдання:

• обгрунтувати методику визначення кратності та показника інтенсивності розбавлення стічних вод Долинського нафтогазовидобувного підприємства, які відводять у річки Тур'янку, Саджаву та Лущаву (праві притоки р. Свічі);

- визначити чинники впливу на природний процес самоочищення річок.

Матеріал та методи дослідження. Підприємства нафтогазового комплексу за рівнем шкідливого впливу на довкілля вважають об'єктами підвищеного екологічного ризику. Причиною забруднення поверхневих вод у процесі нафтогазовидобутку та транспортування переважно $є$ аварії промислових і магістральних нафтогазопроводів, а також фільтрація нафти і стічних вод 3 нафтових і шламових амбарів (Plaksii, 2016).

Стан малих річок $є$ індикатором стану всієї річкової мережі кожної країни. Серед основних причин деградації та забруднення малих річок $є$ зміна гідрологічного режиму внаслідок замулення русел; екстенсивне використання водних ресурсів без урахування можливостей

Інформація про автора:

Гринюк Вікторія Ігорівна, аспірант. Email: victoriagrynuk@gmail.com; https://orcid.org/0000-0003-4816-8614

Цитування за ДСту: Гринюк В. І. Дослідження процесів самоочищення правих приток річки свічі басейну Дністра. Науковий вісник НЛТУ України. 2018, т. 28, № 3. С. 77-82.

Citation APA: Hryniuk, V. I. (2018). Research of the Processes of Self-Cleaning of the River Svicha Right Tributaries in Dniester River Basin. Scientific Bulletin of UNFU, 28(3), 77-82. https://doi.org/10.15421/40280316 
їх самовідновлення та самоочищення; використання старих технологій очищення промислових стоків, які $\epsilon$ причиною антропогенного навантаження на річкові екосистеми.

Оскільки малі річки є початковою ланкою річкової мережі, то всі зміни в їхньому режимі та якості води позначаються на всій гідрографічній мережі. Тому так важливо здійснювати спеціальні комплексні заходи для захисту малих річок від зменшення водності, забруднення та пересихання і спрямовувати їх на ліквідацію негативного впливу антропогенних чинників.

Процеси самоочищення відбуваються дуже повільно та на значних ділянках від місця скидання стічних вод. Проте здатність річок самоочищатися має межі. У невеликих і особливо непроточних водоймах здатність до самоочищення незначна. Вичерпування здатності до самоочищення внаслідок тривалого та надмірного надходження неочищених або недостатньо очищених стічних вод неминуче призводить до забруднення водоймища. А це після використання його населенням для господарсько-питних або культурно-побутових цілей може призвести до негативних наслідків для здоров'я людей.

Самоочищення природних водотоків відбувається під впливом таких надзвичайно різноманітних чинників, що діють одночасно в різних поєднаннях (Karpets, 2014):

а) гідравлічні - розведення і змішування забруднень 3 основною масою води;

б) механічні - осадження зважених частинок;

в) фізичні - вплив сонячної радіації і температури;

г) хімічні - окислювання органічних і мінеральних забруднень; вони визначаються за БСК (біологічним споживанням кисню), ХСК (хімічним споживанням кисню) або за загальним вмістом органіки;

д) біологічні - рослинний і тваринний світ, що бере участь у самоочищенні.

Механізми та швидкість процесів самоочищення природних водойм залежать від природи та властивостей забруднювальних речовин, а також від їх кількості. Коли у водойму скидають незначну кількість неочищених або недостатньо очищених стічних вод, починаючи 3 місця їх випуску, органічні речовини піддаються біохімічному розщепленню. Встановлено, що біоценози мікроорганізмів вздовж течії річки чітко розмежовуються на зони сапробності. Якщо стічні води скидати в невеликі річки, то вони майже по всій довжині, а великі річки на відстані до 60 км, фактично, виконують функцію очисної споруди.

Процес самоочищення водойми від забруднень можна поділити на дві стадії: розбавлення внаслідок перемішування забрудненого струменя масою води і безпосередньо самоочищення. У проточній водоймі внесені в неї стічні води разом із річковою водою, що розбавляє їх, рухаються за течією річки. При цьому розрізняють такі зони: випуску стічних вод, практично повного змішування стічних вод із водою водойми; найбільшого забруднення; відновлення, де закінчується процес самоочищення. Інтенсивність процесу самоочищення залежить від таких чинників:

- місця розташування природних водотоків (географічний чинник);

- морфометричних характеристик водотоків (швидкості течії, глибини);

- кліматичних та мікрокліматичних умов, гідрологічного режиму, стану грунтів та рослинності;
- впливу людської діяльності (антропогенний чинник).

Після розливу нафти внаслідок виникнення аварій на свердловинах та надходження нафтопродуктів із стічними водами від нафтогазовидобувних підприємств відбувається біохімічне окислення, внаслідок чого нафтопродукти розкладаються на вуглекислоту і воду. Проте цей процес відбувається повільно та залежить від кількості розчиненого у воді кисню, температури, кількості мікроорганізмів, що містяться у воді. Влітку плівка нафтопродуктів розкладається на 50-80 \% протягом 5-7 діб, за температури нижче $10{ }^{\circ} \mathrm{C}$ процес відбувається повільніше, а за температури $4{ }^{\circ} \mathrm{C}$ не розкладається взагалі. Донні відклади нафтопродуктів видаляються ще повільніше, навіть під час паводка водойми не звільняються від них.

Таким чином, вони стають джерелом вторинного забруднення середовища. Наявність поверхневої плівки нафтопродуктів у донних відкладах призводить до зменшення вмісту у воді розчиненого кисню та отруєння мікроорганізмів, різкого уповільнення процесу природного самоочищення водойм.

Об'єктами дослідження обрано річки Тур'янка, Саджава та Лущава (праві притоки р. Свічі), в які здійснюється водовідвід стічних вод Долинського нафтогазовидобувного підприємства. Ця територія Передкарпатського гідрологічного району, де живлення підземних водоносних горизонтів і поверхневих водних об'єктів відбувається переважно завдяки інфільтрації та стіканню атмосферних опадів. Підйом рівня води тісно пов'язаний 3 кліматичними умовами території, який спостерігають навесні - під час танення снігу, влітку під час паводків, а взимку - під час відлиг. Мінімальні витрати води у водотоках спостерігають протягом усього року з переважанням в осінній та зимовий період, інколи бувають влітку.

Мінералізація та склад річок Тур'янка, Саджава та Лущава має сезонний характер завдяки зміненню протягом року різних видів живлення. У разі зростання поверхневого живлення мінералізація річкової води може знижуватись. А після зростання підземного живлення води мінералізація річкової води може збільшуватись.

Після очищення зворотні води допоміжних підрозділів Долинського підприємства нафтогазової промисловості відводяться у річки Тур'янку (випуск № 1 та 4), Саджаву (випуск № 2) та Лущаву (випуск № 3).

Спочатку відбувається змішування та розбавлення забрудненої стічної води 3 водою річки. Зниження концентрацій забруднювачів відбувається після багаторазового (1:7-1:10) розведення чистою водою. Величиною, що показує у скільки разів у розрахунковому створі збільшився об'єм води, що бере участь у розбавленні стоку, стосовно первинного об'єму стічних вод на розглянутій ділянці річки, є значення кратності розбавлення.

Кратність розбавлення стічних вод n визначаємо методом Фролова-Родзиллера [Rodzyller, 1984]

$$
n=\frac{\gamma \cdot Q+q_{c \kappa .}}{q_{c \kappa}},
$$

де: $\gamma$ - коефіцієнт, який враховує ступінь повноти змішування та розбавлення стічних вод у водному об'єкті; $Q$ - мінімальна витрата води водотоку в контрольному створі скиду стічних вод, $\mathrm{m}^{3} / \mathrm{c} ; q_{c \kappa}$. - витрата стічних вод, що надходять у річку, $\mathrm{m}^{3} / \mathrm{c}$.

Коефіцієнт $\gamma$ визначаємо за формулою 


$$
\begin{gathered}
\gamma=\frac{1-\beta}{1+\frac{Q}{q_{c k}} \cdot \beta}, \\
\text { де } \quad \beta=e^{-\alpha \sqrt[3]{L}}=\frac{1}{2,72^{\alpha \sqrt[3]{L}}},
\end{gathered}
$$

де: $e$ - основа натурального логарифма, що дорівнює 2, $72 ; L$ - відстань від місця випуску до контрольного створу по фарватеру річки, м; $\beta$ - коефіцієнт, що враховує гідравлічні чинники змішування.

Коефіцієнт $\alpha$ визначаємо за формулою

$$
\alpha=\phi \zeta \cdot \sqrt[3]{\frac{Д}{q_{c k}}}
$$

де: $\varphi$ - коефіцієнт звивистості русла річки, який визначають як відношення відстані від місця випуску стічних вод до контрольного створу по фарватеру $l_{\phi}$ до відстані між цими пунктами по прямій, тобто $\varphi=l_{\phi} / l$. Для розрахунку приймаємо $\varphi=1$, який $\epsilon$ однаковим для річок Тур'янка, Саджава та Лущава. Коефіцієнт $\zeta$ обираємо залежно від випуску стічних вод. Якщо водовідвід стічних вод здійснюється біля берега, то $\zeta=1$; якщо в стрижні річки, то $\zeta=1,5$.

Оскільки Долинське підприємство нафтогазової промисловості здійснює випуск стічних вод у притоки p. Свічі на відстані 0,1 м від берега, то коефіцієнт $\zeta$ становить 1. Д - коефіцієнт турбулентної дифузії (табл. 1).

Витрата води річки є гідрометричною характеристикою, що $\epsilon$ мінливою в часі. Її визначають дослідним шляхом відповідні гідрометеорологічні організації. Оскільки річки мають неоднаковий стік як за роками, так i протягом року, то для розрахунків беруть найгірші умови, тобто найменші середньомісячні витрати $95 \%$ забезпеченості.

У місці випуску стічних вод кратність розбавлення дорівнює одиниці $\left(n_{b}=1\right)$, а $з$ віддаленням від місця випуску в розбавленні стоку бере участь щоразу більший об'єм води, і кратність розбавлення збільшується.

3 аналізу показників кратності розбавлення води за чотирма випусками підприємства нафтогазової промисловості (див. табл. 1) та швидкостей течій правих приток р. Свічі підтверджено закономірність: із збільшенням швидкості течії річки підвищується кратність розбавлення. Тому за найбільшої швидкості течії р. Саджави $0,24 \mathrm{~m} / \mathrm{c}$ (порівняно із швидкостями течій річок Тур'янка та Лущава) кратність основного розбавлення стічних вод становить 103,83. Це означає, що загалом вода стала в 100 раз чистіша в розрахунковому створі внаслідок розбавлення стоку стосовно початкового об'єму стічних вод на розглянутій ділянці р. Саджави.

Потрібно зазначити, що концентрація конкретної забруднювальної речовини у стічних водах і у воді водойми зазвичай відрізняється. Від іï величини залежить швидкість зниження вмісту домішки у воді. Тому, окрім кратності розбавлення стоків, процес розбавлення характеризується ще й показником інтенсивності процесу розбавлення стічних вод, який розраховуємо за формулою (Rodzyller, 1984)

$$
n=\frac{C_{0}-C_{B}}{C-C_{B}},
$$

де: $C_{0}$ - концентрація забруднювальної речовини, що міститься у стічних водах, які відводять у природні во- дотоки; $C_{B}$ і $C$ - концентрація забруднювальної речовини у водоймі до і після випуску відповідно.

Табл. 1. Розрахункова кратність розбавлення води від місця випуску стічних вод до контрольного створу по фарватеру правих приток річки Свічі

\begin{tabular}{|c|c|c|c|c|}
\hline Параметр & $\begin{array}{c}\text { Випуск } \\
\text { № 1 } \\
\text { (р. Тур'ян- } \\
\text { ка) }\end{array}$ & $\begin{array}{c}\text { Випуск } \\
\text { № 2 } \\
\text { (р. Саджа- } \\
\text { ва) }\end{array}$ & $\begin{array}{c}\text { Випуск } \\
\text { № 3 } \\
\text { (р. Лущава) }\end{array}$ & $\begin{array}{c}\text { Випуск } \\
\text { № 4 } \\
\text { (р. Тур'ян- } \\
\text { ка) }\end{array}$ \\
\hline$Q, \mathrm{~m}^{3} / \mathrm{c}$ & 0,027 & 0,061 & 0,0034 & 0,027 \\
\hline$q, \mathrm{M}^{3} / \mathrm{c}$ & 0,00119 & 0,00017 & 0,001 & 0,0028 \\
\hline$L, \mathrm{M}$ & \multicolumn{4}{|c|}{500} \\
\hline$D$ & 0,00033 & 0,00053 & 0,00012 & 0,00033 \\
\hline $\begin{array}{c}\text { Кратність } \\
\text { основного } \\
\text { розбавлен- } \\
\text { ня, } n\end{array}$ & 23,15 & 103,83 & 4,4 & 96,26 \\
\hline
\end{tabular}

Відповідно до вимог ст. 32 Водного кодексу України, скид зворотних вод у відкриті водотоки проводять на основі розробленого та затвердженого документа "Проекту гранично допустимих скидів (ГДС) речовин, що надходять у водні об'єкти зі стічними водами". Проект нормативів ГДС речовин для НГВУ "Долинанафтогаз" затверджено й узгоджено для чотирьох випусків стічних вод.

Щоквартально це підприємство проводить гідрохімічний моніторинг поверхневих та підземних вод. Проби поверхневих вод відбирають безпосередньо в місці скиду стічних вод і 500 м вище та 500 м нижче випуску стічних вод. Проаналізувавши статистичні дані екологічного моніторингу Долинського підприємства нафтогазової промисловості за 2007-2016 рр., виявлено перевищення ГДК за такими компонентами: хлориди, амоній сольовий, азот амонійний, нітрити, БСК.

На основі щоквартальних даних відбору проб води було обчислено середнє значення концентрацій хімічних елементів за рік у місці скиду стічних вод і 500 м вище та 500 м нижче випусків №1, 2, 3, 4. Для розрахунку показника інтенсивності розбавлення води обрали ті елементи, які перевищують норматив ГДК.

Оскільки вміст нафтопродуктів у воді правих приток р. Свічі в межах норми (не більше 0,05 мг/дм³), то інтенсивність розбавлення для нафтопродуктів не обчислювали. Під час розрахунку показника інтенсивності розбавлення води було виявлено, що значення концентрації досліджуваних хімічних елементів 500 м вище випусків № 1, 2, 4 перевищують значення концентрації забруднювальних речовин у місці скиду стічних вод Долинського нафтогазового підприємства. Це пов'язано з наявністю скиду зворотних вод Центральною районною лікарнею міста Долини в р. Тур'янку (табл. 2, 5).

Найбільша кількість забруднювальних речовин надходить у р. Саджаву від деревообробного підприємства "Уніплит", що розташоване на відстані 12 км вище від випуску стічних вод № 2 (Hryniuk, 2017). Про це свідчать від'ємні значення показника інтенсивності розбавлення води (табл. 3).

На р. Лущаву впливають тільки стічні води від нафтогазового підприємства. Результат розрахунку показника інтенсивності розбавлення стічних вод, що надходять у річку за період 2007-2012 рр., показав нульове значення, а це свідчить про відсутність самоочищення води на досліджуваній ділянці р. Лущави. За період 2013-2016 рр. спостерігаємо тенденцію до збільшення інтенсивності розбавлення стічних вод (табл. 4). 
Табл. 2. Показник інтенсивності розбавлення води при випуску № 1 (р. Тур'янка)

\begin{tabular}{|c|c|c|c|c|c|}
\hline Рік & $\mathrm{Cl}$ & $\mathrm{NH}_{4}$ & $\mathrm{NO}_{2}$ & БСК $_{5}$ & $\begin{array}{c}\text { Азот амо- } \\
\text { нійний }\end{array}$ \\
\hline 2007 & 5,2 & $-3,2$ & 1,2 & 2,8 & 0,3 \\
\hline 2008 & 10 & 2,4 & $-0,6$ & 1,9 & 2,5 \\
\hline 2009 & 3,7 & 3,7 & 2,4 & 0 & 4,5 \\
\hline 2010 & 1 & 2,6 & 1,4 & 0,4 & 2,8 \\
\hline 2011 & $-6,3$ & 1,3 & $-0,3$ & $-16,6$ & 1,4 \\
\hline 2012 & 15,3 & $-0,8$ & 0 & $-22,1$ & $-1,1$ \\
\hline 2013 & 7,6 & 0,8 & 5,1 & 3,1 & 11 \\
\hline 2014 & -14 & -10 & 0 & 2 & 0,5 \\
\hline 2015 & 5,3 & 3,5 & $-1,5$ & 2,4 & 4,2 \\
\hline 2016 & 18,2 & 3,25 & -9 & 0,33 & 3 \\
\hline
\end{tabular}

Табл. 3. Показник інтенсивності розбавлення води після випуску № 2 стічних вод (р. Саджава)

\begin{tabular}{|c|c|c|c|c|c|}
\hline Роки & $\mathrm{Cl}$ & $\mathrm{NH}_{4}$ & $\mathrm{NO}_{2}$ & БСК $_{5}$ & $\begin{array}{c}\text { азот амо- } \\
\text { нійний }\end{array}$ \\
\hline 2007 & 39 & -20 & 1,5 & 2,2 & 0 \\
\hline 2008 & 5,3 & 18,8 & 5,3 & 0 & 23,1 \\
\hline 2009 & 6,6 & 15,3 & 4,8 & 7,7 & $-5,3$ \\
\hline 2010 & 4 & 3,7 & 5,5 & 26,9 & 3,3 \\
\hline 2011 & $-1,5$ & 2,9 & 2,4 & 4,3 & 2,9 \\
\hline 2012 & $-0,5$ & $-9,5$ & 2,7 & 4 & -5 \\
\hline 2013 & $-0,6$ & 5 & 0 & 5 & $-1,2$ \\
\hline 2014 & $-0,3$ & $-8,9$ & $-11,6$ & 6,5 & $-8,8$ \\
\hline 2015 & $-1,3$ & 12,4 & 3,75 & 8,9 & 11 \\
\hline 2016 & $-1,28$ & 5,8 & 0 & 30,2 & 6,1 \\
\hline
\end{tabular}

Табл. 4. Показник інтенсивності розбавлення води після випуску № 3 стічних вод (р. Лущава)

\begin{tabular}{|c|c|c|c|c|c|}
\hline Рік & $\mathrm{C}_{1}$ & $\mathrm{NH}_{4}$ & $\mathrm{NO}_{2}$ & БСК $_{5}$ & $\begin{array}{c}\text { Азот } \\
\text { амо- } \\
\text { нійний }\end{array}$ \\
\hline 2013 & $-0,6$ & 6,3 & 0,4 & 0,7 & 6,01 \\
\hline 2014 & 1,6 & 12,5 & $-4,5$ & 0,7 & 9,4 \\
\hline 2015 & 1,2 & 12,3 & 2,1 & 1,2 & 0,8 \\
\hline 2016 & $-0,6$ & 6,2 & 0,4 & 0,6 & 6,01 \\
\hline
\end{tabular}

Табл. 5. Показник інтенсивності розбавлення води після випуску № 4 стічних вод (р. Тур'янка)

\begin{tabular}{|c|c|c|c|c|c|}
\hline Рік & $\mathrm{Cl}$ & $\mathrm{NH}_{4}$ & $\mathrm{NO}_{2}$ & БСК $_{5}$ & $\begin{array}{c}\text { Азот амо- } \\
\text { нійний }\end{array}$ \\
\hline 2007 & 1,6 & $-0,9$ & 1,5 & $-2,1$ & -1 \\
\hline 2008 & 8,2 & 4 & 2,8 & 11 & 7,5 \\
\hline 2009 & 2,8 & $-1,6$ & 0 & $-17,5$ & -4 \\
\hline 2010 & 2,7 & 3,9 & 4 & 0,8 & 5 \\
\hline 2011 & 2,3 & 1,2 & $-1,9$ & 2,3 & 1 \\
\hline 2012 & $-0,5$ & 0,7 & -3 & 1,75 & 0,82 \\
\hline 2013 & $-0,04$ & 0 & 0,1 & 6 & $-6,8$ \\
\hline 2014 & 0,3 & 1 & 6,2 & 1,45 & 1 \\
\hline 2015 & 10,9 & -5 & 1,4 & 4 & 0,22 \\
\hline 2016 & $-0,44$ & 8,7 & 0 & $-4,5$ & $-2,8$ \\
\hline
\end{tabular}

Важливим чинником самоочищення води від забруднювальних речовин $\epsilon$ процес окислення органічних речовин, який залежить від кількості кисню, що надходить 3 атмосфери. Збільшення швидкості течії річки сприяє насиченню води киснем. Найбільше перевищення нормативу ГДК у стічних водах зафіксовано за БСК $_{5}$, який характеризує забруднення водойми органічними речовинами. Тому варто докладніше дослідити зміну цього показника в часовій динаміці.

Максимальне значення БСК після випуску № 1 стічних вод зафіксовано у 2011 р. та становить $10,15 \mathrm{MгO}_{2} /$ дм $^{3}$, що у 3,3 раза перевищує ГДК (3 $\mathrm{MгO}_{2} /$ дм$\left.^{3}\right)$. Динаміка зміни БСК 5 (випуск № 1) свідчить про невідповідність значень цього показника нормативу ГДК (рис. 1). Це означає, що процес самоочищення води на відстані 1000 м відбувається дуже повільно.

Аналогічне максимальне перевищення значення БСК $_{5}$ виявлено також у 2011 р. (у 3,3 раза). Проте зна- чення БСК 5 досягає свого піку у 2010 р. (у 29 раз перевищує норматив ГДК) вище випуску № 2 за цілий період дослідження (рис. 2). Причиною цього є скид недостатньо очищених стічних вод від деревообробного підприємства "Уніплит", яке відводить у р. Саджаву найбільше об'ємів зворотних вод. Про це свідчать дані моніторингу Івано-Франківського обласного управління водних ресурсів.

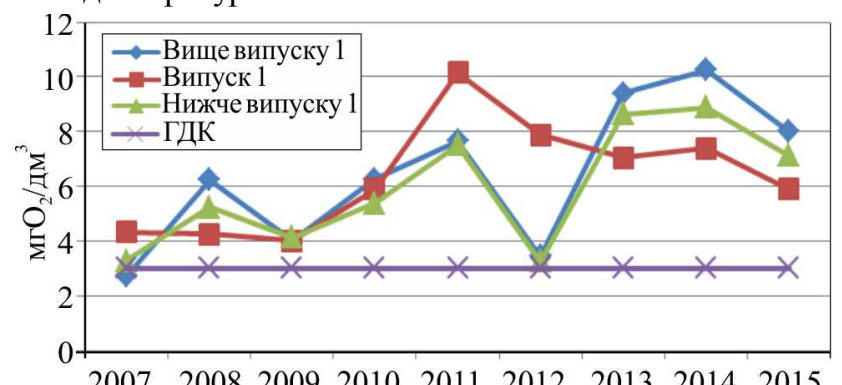

Рис. 1. Динаміка зміни БСК 5 на ділянці 500 м вище та нижче випуску № 1 (р. Тур'янка)

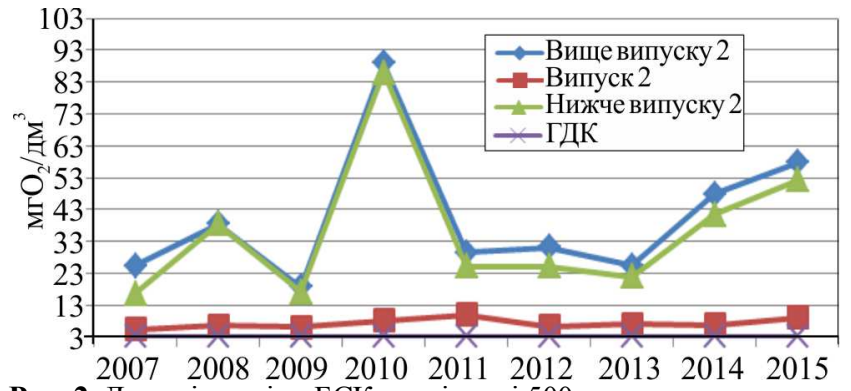

Рис. 2. Динаміка зміни БСК 5 на ділянці 500 м вище та нижче випуску №2 (р. Саджава)

Аналізуючи динаміку зміни біохімічного споживання кисню у річці Лущаві (рис. 3), виявлено перевищення нормативу ГДК у місці випуску стічних вод нафтогазового підприємства в 3,5-8,7 раза. Максимальне значення БСК 5 зафіксовано у 2011 р. $\left(26,1 \mathrm{мгO}_{2} /\right.$ дм$\left.^{3}\right)$.

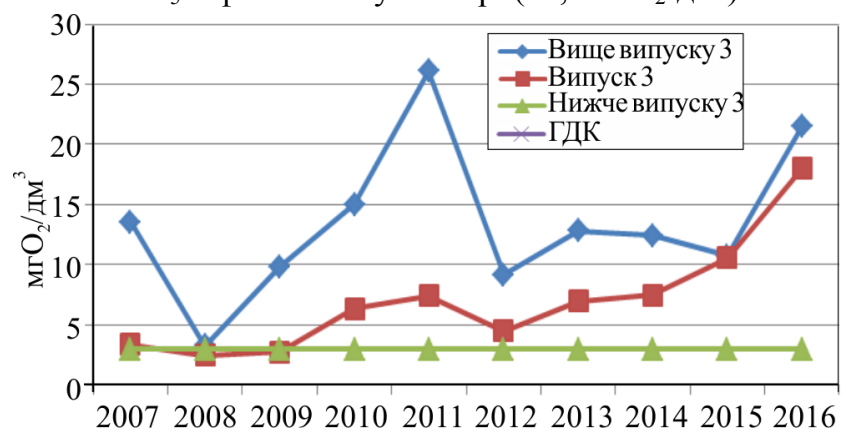

Рис. 3. Динаміка зміни БСК 5 на ділянці 500 м нижче випуску №3 та у місці скиду стічних вод (р. Лущава)

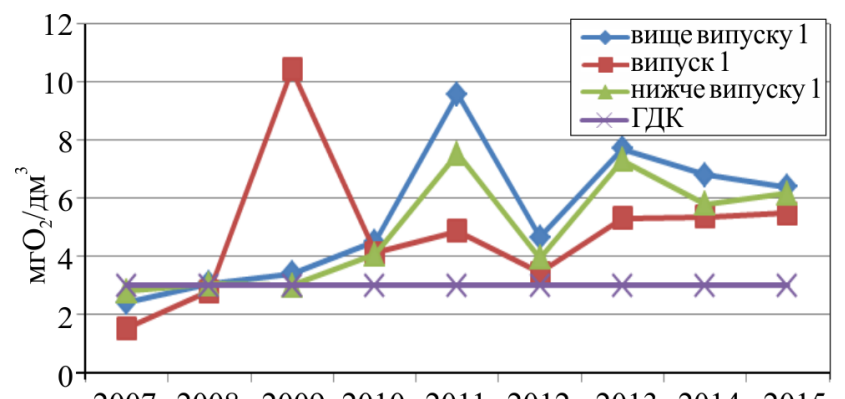

200720082009201020112012201320142015

Рис. 4. Динаміка зміни БСК 5 на ділянці 500 м вище та нижче випуску № 4 (р. Тур'янка)

Значення БСК 5 після випуску № 4 стічних вод відповідає нормативу ГДК тільки у 2007, 2008 рр., далі від- 
бувається перевищення. Найбільше значення БСК 5 становило 10,4 мгО ${ }_{2} /$ дм $^{3}$ у 2009 р. (рис. 4). Виявлено, що за максимального показника БСК 5 після випуску стічних вод спостерігають мінімальне значення БСК 5 нижче випуску № 4. У цьому випадку самоочищення відбувається найкраще. Далі за кратності основного розбавлення 96,26 відбувається самоочищення води переважно на ділянці 1000 м.

Висновки. Отже, результати дослідження підтверджують, що процеси самоочищення у невеликих річках басейну Дністра відбуваються досить повільно і на значних ділянках від місця скиду стічних вод. Максимальну кратність основного розбавлення води виявлено для р. Саджави, яка має найбільшу швидкість течії 0,24 м/c, порівняно зі швидкостями течій річок Тур'янки та Лущави $(0,17$ та 0,15 м/с відповідно). Зафіксовано перевищення гранично допустимої концентрації за такими забруднювальними речовинами: хлориди, амоній сольовий, нітрити, азот амонійний та біохімічне споживання кисню (БСК $)$. Розраховано показник інтенсивності розбавлення води для правих приток р. Свічі на відстані 1000 м. Вода річок Тур'янка, Лущава та Саджава на відстані 500 м від скиду недостатньо очищених зворотних вод Долинського підприємства нафтогазової промисловості не встигає відновитись до природного стану. Виявлено, що на якість води р. Саджави значно впливає ТОВ "Уніплит", а на якість води р. Тур'янки Центральна районна лікарня м. Долини, випуски яких розташовані вище скиду стічних вод Долинського підприємства нафтогазової промисловості. Це означає, що річки Тур'янка та Саджава зазнають подвійного забруднення. Результати дослідження процесу самоочищення правих приток р. Свічі басейну Дністра будуть використані для здійснення прогнозу якості води з часом та прийняття управлінських рішень щодо природоохоронних заходів.

\section{Перелік використаних джерел}

Adamenko, Ya. O., Cheliadin, L. I., et al. (2007). Ekolohichna bezpeka hidrosfery rehioniv, ochyshchennia stichnykh vod ta utylizatsiia shlamiv vodoochyshchennia. Ekotekhnolohyy $y$ resursosberezhenye, 6, 68-73. [In Ukrainian].
Arkhypova, L. M., \& Pernerovska, S. V. (2015). Forecasting water bodies hydrological parameters using singular spectrum analysis. Scientific Bulletin of National Mining University, 2, 4550. [In Ukrainian].

Hryniuk, V. I. (2017). Vyznachennia faktoriv vplyvu na ekolohichnyi stan richky Sadzhavy [Ekoloho-enerhetychni problemy suchasnosti]. Odesa. [In Ukrainian].

Jakubínský, J. (2014). The human impact on the current hydromorphological states of small watercourses in the Czech Republic. Ecohydrology and Hydrobiology, 14(4), 313-322.

Karpets, K. M. (2014). Design factor relief-dependence self-cleaning permanent watercourses city of Kharkov. Liudyna ta dovkillia. Problemy neoekolohii, 3-4, 52-56. [In Ukrainian].

Korchemlyuk, M. V., \& Arkhypova, L. M. (2015). Estimation of key pressures on Prut river basin in Ukraine. Ekolohichna bezpeka, 1(19), 41-45. [In Ukrainian].

Malovanyy, M., et al. (2016). Integrated adsorption and ultrasonic technology for water treatment processes. Environmental Problems, 1, 65-68. [In Ukrainian].

Oshurkevych-Pankivska, O. Ye. (2016). The methods of determination of the estimated water flow in water bodies at calculating the maximum allowable discharges of pollutants with reverse waters. Scientific Bulletin of UNFU, 26(8), 205-210. https://doi.org/10.15421/40260832

Plaksii, L. V. (2016). Metodolohiia otsiniuvannia poverkhnevykh vod $\mathrm{v}$ mistsiakh vplyvu obiektiv naftoprovidnoho transportu. Ekolohichna bezpeka ta zbalansovane resursokorystuvannia, 2(14), 24-28.

Proskurnyn, O. A. (2015). Normyrovanye soderzhanyia rastvorennoho kysloroda $\mathrm{v}$ stochnykh vodakh, postupaiushchykh $\mathrm{v}$ vodnyi obiekt. Technology audit and production reserves, 1(4), 1316. [In Ukrainian].

Rodzyller, I. D. (1984). Prohnoz kachestva vody vodoemovpryemnykov stochnykh vod. Moscow: Stroiyzdat. $262 \mathrm{p}$.

Salla, M. R. (2016). Importance of calibration for mathematical modeling of self-purification of lotic environments. https://oi.org/10.1590/s2179-975x 5016

Swain, R., \& Sahoo, Bh. (2017). Improving river water quality monitoring using satellite data products and a genetic algorithm processing approach. Sustainability of Water Quality and Ecology, 9-10, 88-114. https://doi.org/10.1016/j.swaqe.2017.09.001

Zaharia, Ca. (2017). Decentralized wastewater treatment systems: Efficiency and its estimated impact against onsite natural water pollution status. A Romanian case study. Process Safety and Environmental Protection, 108, 74-88. https://doi.org/10.1016/j.psep.2017.02.004

\section{ИССЛЕДОВАНИЕ ПРОЦЕССОВ САМООЧИЩЕНИЯ ПРАВЫХ ПРИТОКОВ}

РЕКИ СВЕЧИ БАССЕЙНА ДНЕСТРА

Представлены результаты исследований процесса разбавления сточных вод, поступающих в правые притоки реки Свечи бассейна Днестра. Описаны проблемы загрязнения малых рек в пределах влияния нефтегазовой промышленности. Определены факторы влияния на естественный процесс самоочищения рек. Обоснована методика определения кратности и интенсивности процесса разбавления сточных вод в реках Турьянка, Саджава и Лущава. Проанализированы статистические данные экологического мониторинга Долинского предприятия нефтегазовой промышленности за период 2007-2016 гг. На основе ежеквартальных данных отбора проб воды вычислено среднее значение концентраций химических элементов в год в месте сброса сточных вод, 500 м выше и 500 м ниже выпусков № 1, 2, 3, 4 Долинского предприятия нефтегазового комплекca. В результате обнаружено превышение предельно допустимой концентрации по таким загрязняющим веществам: хлориды, аммоний солевой, нитриты, азот аммонийный и биохимическое потребление кислорода (БПК 5 ), по которым осуществлен дальнейший расчет показателя интенсивности разбавления сточных вод в реках Турьянка, Саджава и Лущава. Изображена и проанализирована динамика изменения биохимического потребления кислорода на участке 500 м выше и 500 м ниже места четырех выпусков сточных вод. Проведены расчеты, которые подтверждают закономерность: с увеличением скорости течения реки увеличивается кратность разбавления, а также свидетельствуют о загрязнении правых притоков реки Свечи, естественный процесс самоочищения которых происходит очень медленно.

Ключевые слова: сточные воды; загрязняющие вещества; кратность разбавления; нефтегазовая промышленность; биохимическое потребление кислорода. 
V. I. Hryniuk

Ivano-Frankivsk National Technical University of Oil and Gas, Ivano-Frankivsk, Ukraine

\section{RESEARCH OF THE PROCESSES OF SELF-CLEANING OF THE RIVER SVICHA RIGHT TRIBUTARIES IN DNIESTER RIVER BASIN}

The authors have presented the results of investigations of the dilution process of sewage entering the right tributaries of the Svicha River of the Dniester River basin. The author described the problem of pollution of small rivers due to the influence of oil and gas industry. Moreover, the authors determined the factors influencing the natural process of river self-cleaning. The method of determining the multiplicity and intensity of the process of wastewater diluting in the rivers of Turianka, Sadzhava and Luschava is substantiated. The authors analysed the statistical data on the environmental monitoring of Dolyna Oil and Gas Enterprise for the period of 2007-2016. We calculated the average amount of chemical elements concentrations per year at the place of wastewater discharges, $500 \mathrm{~m}$ above and $500 \mathrm{~m}$ below the issues №.1, 2, 3, 4 of the Dolyna Oil and Gas enterprise on the basis of quarterly water sampling data. As a result, an excess of the permissible concentration for such pollutants as chlorides, ammonium salts, nitrites, ammonium nitrogen and biochemical oxygen demand $\left(\mathrm{BOD}_{5}\right)$, for which further calculation of the intensity of dilution of wastewater dilution in the Turianka, Sadzhava and Luschava rivers was carried out. The studies show that the rivers Turianka and Sadzhava are subject of double contamination, as their water quality is also affected by the wastewater discharge of Dolyna District Hospital and the wood-processing enterprise "Uniplyt Ltd". The authors described and analysed the dynamics of changes in the biochemical oxygen demand in the section $500 \mathrm{~m}$ above and $500 \mathrm{~m}$ below four wastewaters of Dolyna Oil and Gas Enterprise. Consequently, the performed calculations confirm the following regularity: with the increasing river flow velocity, the multiplicity of dilution of sewage increases. It also testifies the pollution of the right tributaries of the Svicha River, where the natural process of self-purification is quite slow.

Keywords: sewage; pollutants; multiplicity of dilution; oil and gas industry; biochemical oxygen demand. 